\title{
SOME RECENT ADVANCES IN THE STUDY OF DEEP-SEA FORAMINIFERAL BIOLOGY AND THEIR PALAEOECOLOGICAL SIGNIFICANCE
}

\author{
GOODAY, Andrew J., Institute of Oceanographic Sciences Deacon Laboratory, Brook Road, \\ Wormley, Godalming, Surrey, GU8 5UB, U.K.
}

During the past two decades, biologists have become increasingly aware of the diversity and abundance of foraminifera in marine benthic ecosystems. These protists are probably the most important eukaryotes present in ocean floor communities. In some areas, particularly central oceanic regions, foraminiferal assemblages are dominated by newly discovered, soft-bodied forms with morphologies quite unlike those of "conventional" foraminifers and with little fossilisation potential. However, despite the presumed loss of these delicate forms from the fossil record, foraminiferal tests are still the only microfossils to occur commonly in ancient deep-sea sediments. Thus, they are a focus of attention for both geologists and biologists. This presentation will concentrate on two main areas of biological research which have palaeontological significance.

Foraminiferal microhabitats. Recent research indicates that particular species tend to live infaunally (deep or shallow), epifaunally or suprabenthically. Growth above or below the sedimentwater interface has major implications for the stable isotope chemistry of calcareous tests, an important tool in palaeooceanography. Other species inhabit organic detritus composed of phytoplankton material rapidly sedimented from the euphotic zone. This "phytodetritus" arrives suddenly on the ocean floor following the spring bloom and is quickly colonized by foraminiferal species which feed on it, reproduce and rapidly develop large populations. These populations collapse when the food source is exhausted. The direct consumption of phytodetritus (and other organic matter inputs) by benthic foraminifers may be a widespread phenomenon which influences their population dynamics, regional distribution patterns and isotope chemistry.

Recolonization. The defaunation of large tracts of ocean floor by turbidity currents or anoxic events must have happened on countless occasions over geological time, particularly along ocean margins and in basinal areas. Evidence from sediment tray experiments suggests that it may take several years for a stable community (including foraminifers) to become reestablished in small areas of defaunated sediment. Large devastated areas may require substantially longer to recover. However, on the Madeira Abyssal Plain, a normal foraminiferal assemblage occurs on the surface of a turbidite deposited several hundred years ago, suggesting that large-scale recolonization may occupy decades rather than centuries. The fossil foraminiferal assemblages present in deep-water flysch sequences are presumably the product of similar recolonization (?successional) events.

These and other biological processes often operate on time scales (days, months, years) which usually can not be resolved in the stratigraphic record. This inevitably complicates the application of biological research to palaeontology. 